\title{
The Electrochemical Properties and Mechanism of Formation of Anodic Oxide Films on Mg-Al Alloys
}

\author{
Seong-Jong Kim ${ }^{*}$ and Masazumi Okido* \\ Graduate School of Engineering, Nagova Unversity. Furo-cho, Chikusa-ku, Nagova +6t-8603. Japan \\ Received March 24, 2003
}

\begin{abstract}
The electrochemical properties and the mechanism of formation of anodic oxide films on $\mathrm{Mg}$ alloys containing 0.15 mass $\% \mathrm{Al}$, when anodized in $\mathrm{NaOH}$ solution, were investigated by focusing on the effects of anodizing potential. Al content, and anodizing time. The intensity ratio of $\mathrm{Mg}(\mathrm{OH})_{2}$ in the XRD analysis decreased with increasing applied potential, while that of $\mathrm{MgO}$ increased. $\mathrm{Mg}(\mathrm{OH})_{2}$ was barely detected at $80 \mathrm{~V}$, while $\mathrm{MgO}$ was readily detected. The anti-corrosion properties of anodized specimens at each constant potential were better than those of non-anodized specimens. The specimen anodized at an applied potential of $3 \mathrm{~V}$ had the best anti-conrosion property. The intensity ratio of the $\beta$ plase increased with aluminum content in $\mathrm{Mg}$ - $\mathrm{Al}$ alloys. During anodizing, the active dissolution reaction occurned preferentially in $\beta$ phase until about $4 \mathrm{~min}$ and then the current density increased gradually until $7 \mathrm{~min}$. The dissolution reaction progressed in $\alpha$ phase, which had a lower Al content. In the anodic polarization test in $0.017 \mathrm{~mol} \cdot \mathrm{dm}^{-2} \mathrm{NaCl}$ and $0.1 \mathrm{~mol} \cdot \mathrm{dm}^{-3} \mathrm{Na}_{2} \mathrm{SO}_{4}$ at $298 \mathrm{~K}$. the current density of $\mathrm{Mg}-15$ mass\% $\mathrm{Al}$ alloy anodized for 10 min increased. since the anodic film that forms on the $\alpha$ phase is a non-compacted film. The anodic film on the $\alpha$ phase at 30 min was a compact film as compared with that at $10 \mathrm{~min}$.
\end{abstract}

Key Words : Anodizing. Electrochemical properties. $\mathrm{Mg}$-Al alloỵs. Anti-corrosion property

\section{Introduction}

Of the common metals. magnesium has the lowest density: it also has excellent specific strength. Magnesium must be surface treated to prevent corrosion. since it is a very active metal electrochemically. There are many ways to treat the surface of magnesium and its alloys. including anodizing. painting. and electroplating. Dow 17 bath is generally used to anodize magnesium alloys in the commercial chemical industry. However. Dow 17 bath. which contains chromate and fluoride causes many problems for humans and the environment and is difficult to recycle. Furthermore. it is deemed a Class 1 carcinogenic substance in the Pollutant Release and Transfer Register (PRTR). ${ }^{l}$ In Europe. the use of lead. mercury. cadmium. and $\mathrm{Cr}^{+} \mathrm{in}$ in electronic products is prohibited. A waste electrical and electronic equipment (WEEE) collection plan was announced in June 2000. The use of $\mathrm{Cr}^{+6}$ will gradually be phased out and prohibited by the year 2007. In addition. the environmental load value (ELV) order restricting the use of environmental load substances will be implemented incrementally beginning in July 2003. The use of $\mathrm{Cr}^{+6}$ by the automobile industry is prohibited after July $2007 .^{3}$ We have therefore been investigating alternatives to chromate baths for $\mathrm{Mg}$ alloys. ${ }^{+-7}$ Anodizing magnesium alloy's generates multi-porous films several tens of micrometers thick. The anodic behavior of magnesium in $\mathrm{NaOH}$ solutions at a wide range of potentials was first described in the studies of Emley ${ }^{8}$ Huber. ${ }^{5}$ and Exangelides. ${ }^{10}$ Only' a few investigations have examined the growth behavior of anodic oxide surface films on magnesium. ${ }^{8} \mathrm{Mg}-\mathrm{Al}$ alloys.$^{5.1-13}$ and

\footnotetext{
${ }^{*}$ Corresponding author. E-mail: kimiạ fz.numse.nagoya-u.ac.jp
}

aluminum. ${ }^{14}$ Khaselev et al. reported the anodic behavior of binary $\mathrm{Mg}$ - $\mathrm{Al}$ alloy's in $\mathrm{KOH}$ solutions over a wide range of applied potentials. emphasizing the effect of aluminum content on the passivation phenomena and spark potential. ${ }^{13}$ It has also been reported that the effect on an anodizing film of aluminum ions in the solution is more remarkable than that of the $\mathrm{Al}$ added to $\mathrm{Mg}-\mathrm{Al}$ alloys. The current density during anodizing effectively decreases with increasing $\mathrm{AlO}_{2}^{-}$content in the solution. ${ }^{15.16}$

This study characterized anodic oxide films. using parameters such as the anodizing potential. anodizing time. and $\mathrm{Al}$ content of $\mathrm{Mg}-\mathrm{Al}$ alloys in $1.0 \mathrm{~mol} \cdot \mathrm{dm}^{-3} \mathrm{NaOH}$ solution at $298 \mathrm{~K}$ and the mechanism of anodic oxide film formation. The anodized film was analyzed using electrochemical techniques: scanning electron microscopy (SEM). X-ray diffraction analysis (XRD), and energy dispersive $\mathrm{X}$-ray spectrometry (EDX)

\section{Experimental Section}

$\mathrm{Mg}-\mathrm{Al}$ alloy's were prepared by melting a mixture of pure metals at $1073 \mathrm{~K}$ and allowing the mixture to solidify rapidly. This process was repeated twice to prevent segregation of the aluminum. The homogeneous distribution of $\mathrm{Al}$ in the alloy was confirmed by ICP-AES (SPS-1500 VR). The purity of the prepared alloy was 99.9 mass $\%$ for $\mathrm{Mg}$ and 99.999 mass \% for Al. Alloy electrodes were mounted using epoxy resin. leaving an exposed area of $100 \mathrm{~mm}^{2}$. and polished with $0.05-\mu \mathrm{m}$ alumina powder. The specimens were carefully degreased with acetone and water. The constant potential experiment system consisted of a Pt coil as a counter electrode. and an $\mathrm{Ag} / \mathrm{AgCl}$ sat. $\mathrm{KCl}$ reference 
electrode. The experiments were conducted in $250 \mathrm{~mL}$ of 1 $\mathrm{mol} \cdot \mathrm{dm}^{-3} \mathrm{NaOH}$ alkaline solution at $298 \mathrm{~K}$. The distance between the working and counter electrodes was approximately $50 \mathrm{~mm}$. The solution was stirred during all of the experiments. The Mg alloy's were anodized at constant potentials of 3. 10.40 and $80 \mathrm{~V}$. The anodic polarization curves of specimens anodized at various potentials were measured in a solution containing $0.017 \mathrm{~mol} \cdot \mathrm{dm}^{-3} \mathrm{NaCl}$ and $0.1 \mathrm{~mol} \cdot \mathrm{dm}^{-3}$ $\mathrm{Na}_{2} \mathrm{SO}_{4}$ at $298 \mathrm{~K}$ at a scan rate of $1 \mathrm{mVs}^{-1}$. in order to characterize the corrosion resistance of the anodizing films. The anodizing films were also evaluated using SEM. XRD. and EDX.

\section{Results and Discussion}

First the $\mathrm{Al}$ content at the surface of the $\mathrm{Mg}-\mathrm{Al}$ alloy's was examined using XRD. Figure l(a) shows typical XRD patterns of Mg-Al alloy's containing 1.5, 3, 7 and 9 mass $\%$ $\mathrm{Al}$ before anodizing. Magnesium and $\mathrm{Mg}_{17} \mathrm{Al}_{12}$ were clearly detected in the XRD results. $\mathrm{Mg}_{17} \mathrm{Al}_{13}$ is intermetallic compound of 99.9 mass $\%$ for $\mathrm{Mg}$ and 99.999 mass $\%$ for $\mathrm{Al}$. This intermetallic compound. $\mathrm{Mg}_{17} \mathrm{Al}_{1 \text { s. }}$ is $\beta$ phase. $\mathrm{Mg}$

(a)
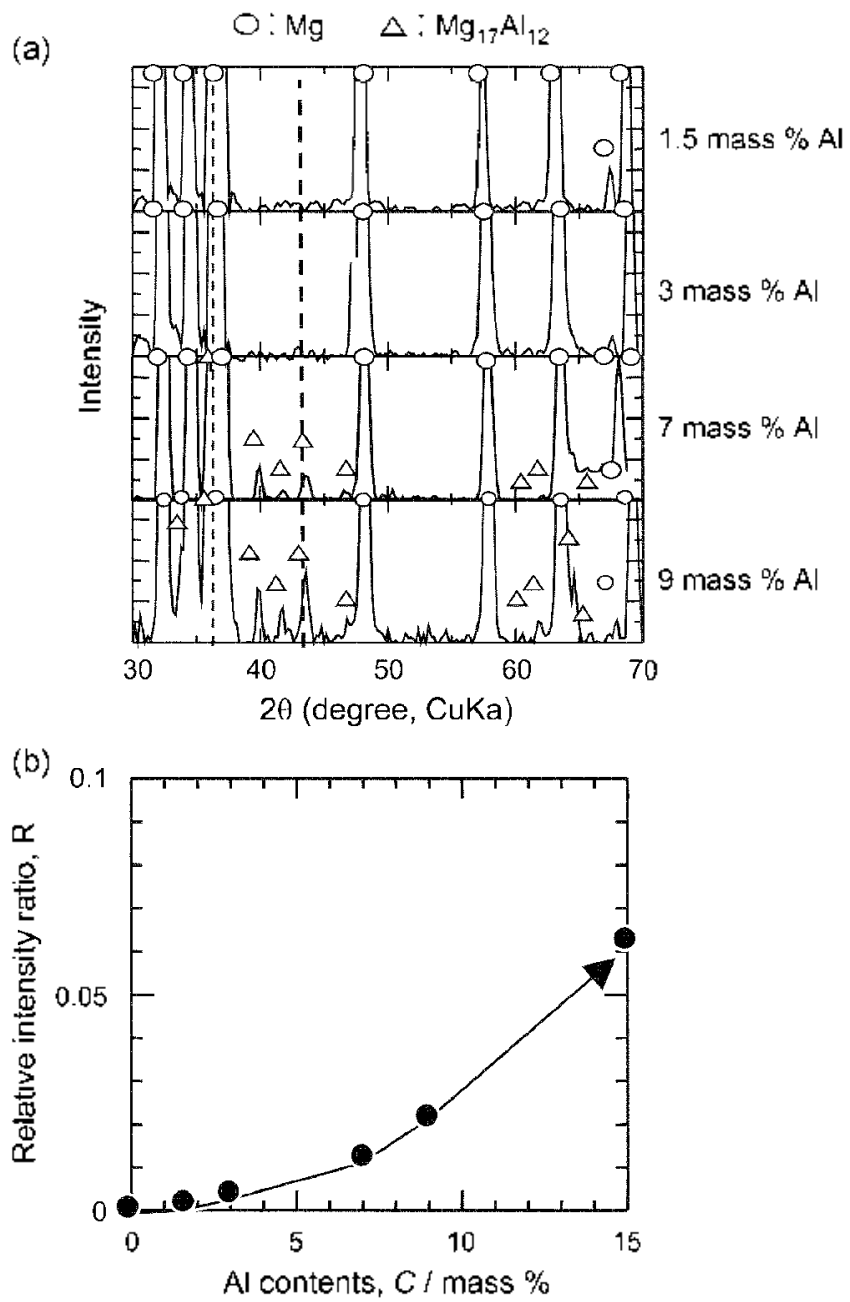

Figure 1. Surface analysis by $\mathrm{XRD}$ of $\mathrm{Mg}-\mathrm{Al}$ alloys with $\mathrm{Al}$ contents. which not formed intermetallic compound is $\alpha$ phase. The highest peaks of $\mathrm{Mg}$ and $\mathrm{Mg}_{17} \mathrm{Al}_{12}$ correspond to 36.8, and $43.6^{\circ}$, respectively. The intensity ratio. $\mathrm{R}$. of $\mathrm{Mg}_{17} \mathrm{Al}_{1} / \mathrm{Mg}$ is defined as the ratio at 43.6 to $36.8^{\circ}$. Figure l(b) shows the change in $\mathrm{R}$ in the alloys. The intensity ratio of $\mathrm{Mg}_{17} \mathrm{Al}_{12}$ increased with increasing $\mathrm{Al}$ content in the $\mathrm{Mg}-\mathrm{Al}$ alloys. $\mathrm{Mg}_{17} \mathrm{Al}_{1}$ ? peaks were barely detected in the $\mathrm{Mg}-\mathrm{Al}$ alloys containing less than 3 mass $\%$ Al. It was not detected intermetallic compound in 1.5 mass $\% \mathrm{Al}$. and 3 mass $\% \mathrm{Al}$. However. intermetallic compound in 7 mass $\% \mathrm{Al}$ was detected from XRD pattern. Therefore. $\mathrm{Mg}$-Al alloỵs containing over 7 mass $\%$ Al were composed of $\alpha$ phase. i.e. $\mathrm{Mg}$. and $\beta$ phase. i.e. $\mathrm{Mg}_{17} \mathrm{Al}_{12}$.

Before anodizing treatment at a constant potential in 250 $\mathrm{mL} \mathrm{NaOH}$ solution, anodic polarization was conducted at a scan rate of $60 \mathrm{mVs}^{-1}$ at $298 \mathrm{~K}$ to investigate the potentials of the active dissolution reaction. passivation. and sparking on the alloy's. An anodic current increment corresponding to
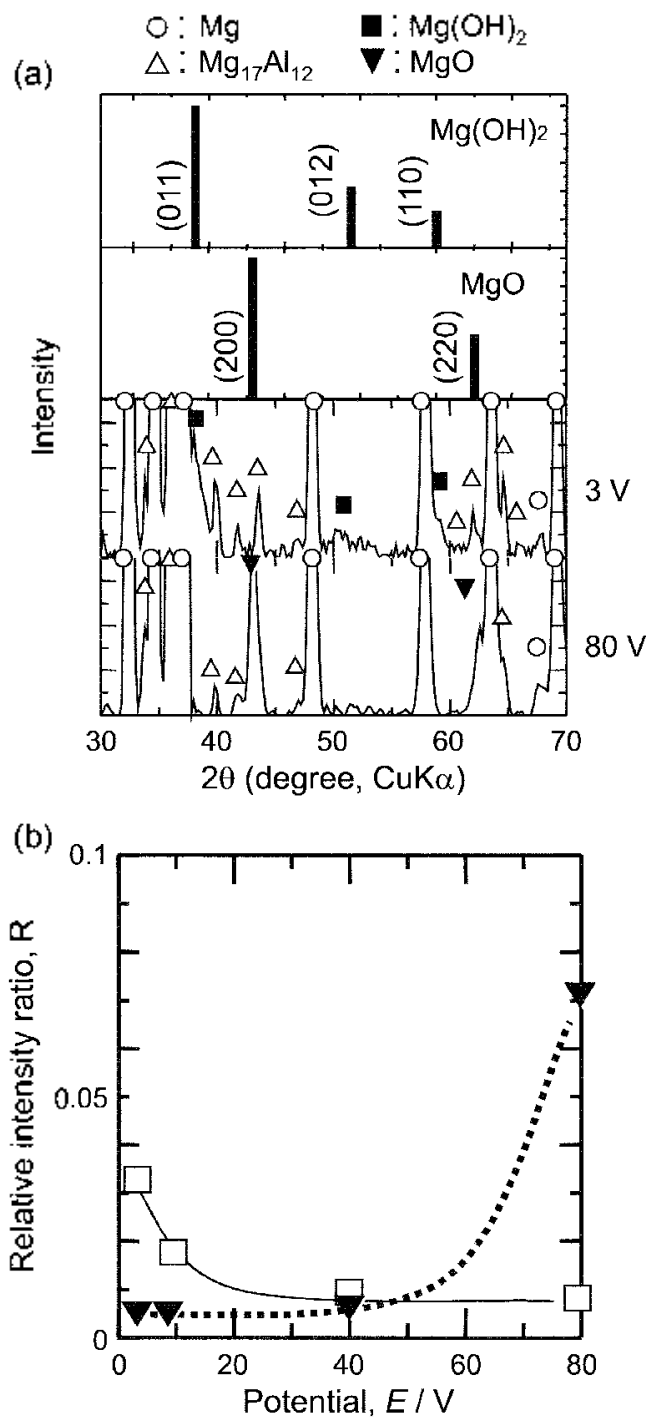

Figure 2. XRD analysis of specimens of $\mathrm{Mg}-9$ mass $\% \mathrm{Al}$ alloy anodized for $10 \mathrm{~min}$ at various constant potentials in $1.0 \mathrm{~mol} \cdot \mathrm{dm}^{-3}$ $\mathrm{NaOH}$ solution at $298 \mathrm{~K}$. 
the active dissolution reaction and the formation of hydroxide. $\mathrm{Mg}=\mathrm{Mg}^{2+}+2 \mathrm{e}^{-} \cdot \mathrm{Mg}^{2-}+2 \mathrm{OH}=\mathrm{Mg}(\mathrm{OH})$. was observed at potentials between 3 and $7 \mathrm{~V}$ for all specimens. ${ }^{5}$ Breakdown with intense sparking was observed at above $80 \mathrm{~V}^{8}$

Next. constant potential anodizing was carried out in 1.0 mol $\mathrm{dm}^{-3} \mathrm{NaOH}$ solution at $298 \mathrm{~K}$. Figure 2(a) shows the XRD patterns of Mg- 9 mass $\%$ Al anodized for $10 \mathrm{~min}$ at various potentials. Peaks of $\mathrm{Mg}(\mathrm{OH})_{2}$ and $\mathrm{MgO}$ were also detected in the XRD analysis. $\mathrm{Mg}(\mathrm{OH})$ ₹ predominated at an applied potential of $3 \mathrm{~V}$. while $\mathrm{MgO}$ appeared at an applied potential of $80 \mathrm{~V}$. The highest peaks of $\mathrm{Mg} . \mathrm{Mg}(\mathrm{OH})$. and $\mathrm{MgO}$ correspond to 36.8 .38 .0 . and $43.0^{\circ}$. respectively. The intensity ratio was calculated in the same manner as in Figure 1. Figure 2(b) shows the intensity ratio at each applied potential. The intensity ratio of $\mathrm{Mg}(\mathrm{OH})_{2}$ decreased with increasing applied potential. while that of $\mathrm{MgO}$ increased. $\mathrm{Mg}(\mathrm{OH})_{2}$ was barely detected at $80 \mathrm{~V}$. while $\mathrm{MgO}$ was strongly detected. These trends were similar to the case of $\mathrm{Mg}-3$ mass\% Al

Figure 3 shows surface photographs of Mg-9 mass\% Al anodized at various potentials for $10 \mathrm{~min}$. The surface was rough at $3 \mathrm{~V}$. due to $\mathrm{Mg}(\mathrm{OH})$ = generated by the surface dissolution reaction. The surface dissolution reaction occurred selectively on the $\alpha$ phase only (white area). The $\alpha$ phase tarnished. due to a dissolution reaction that was minimal on $\beta$ phase. Surfaces anodized at 3,10 . and $80 \mathrm{~V}$ had roughnesses of approximately 1.2 .0 .60 . and $0.12 \mu \mathrm{m}$. respectively. ${ }^{17}$ The surfaces of specimens anodized at 40 and $80 \mathrm{~V}$ were comparatively flat. In addition. the surface of $\mathrm{Mg}-3$ mass $\%$ $\mathrm{Al}$ anodized at $3 \mathrm{~V}$ was very rough, similar to Mg-9 mass\% $\mathrm{Al}$. and was dark gray in color. When anodized at $10 \mathrm{~V}$ the difference in the dissolution reaction of the $\alpha$ and $\beta$ phases was very distinct.

Next. the corrosion behavior of the surface films was examined. Figure 4 shows the anti-corrosion properties in a solution containing $0.017 \mathrm{~mol} \mathrm{dm}^{-3} \mathrm{NaCl}$ and $0.1 \mathrm{~mol} \cdot \mathrm{dm}^{-3}$ $\mathrm{Na}_{2} \mathrm{SO}_{4}$ at $298 \mathrm{~K}$. The specimens used were Mg-9 mass $\% \mathrm{Al}$ alloy anodized for $10 \mathrm{~min}$ at various potentials at $298 \mathrm{~K}$ in 1

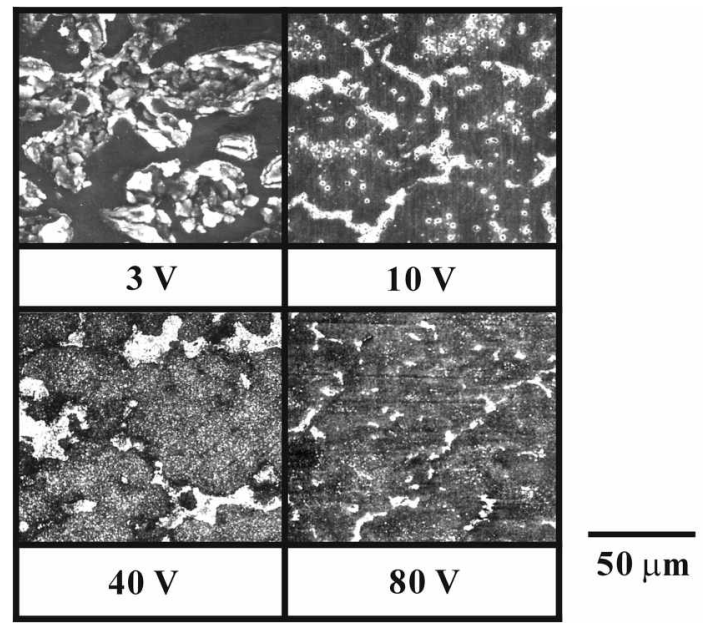

Figure 3. SEM photographs of Mg-9 mass\% Al alloy specimens anodized for $10 \mathrm{~min}$ at various constant potentials in $1.0 \mathrm{~mol} \cdot \mathrm{dm}^{-3}$ $\mathrm{NaOH}$ solution at $298 \mathrm{~K}$.

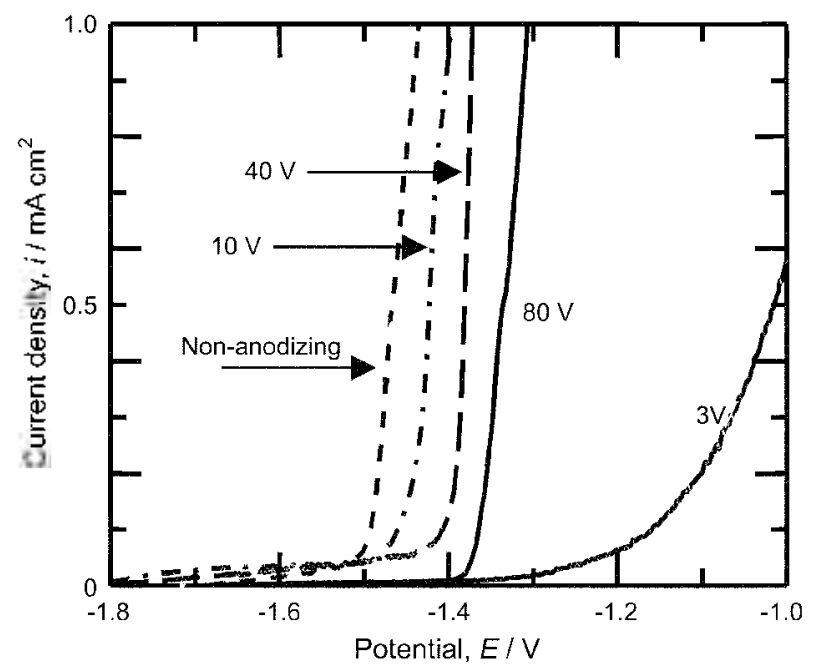

Figure 4. Comparison of the anti-corrosion properties in 0.017 $\mathrm{mol} / \mathrm{dm}^{3} \mathrm{NaCl}$ and $0.1 \mathrm{~mol} \cdot \mathrm{dm}^{-3} \mathrm{Na}_{2} \mathrm{SO}_{4}$ solution at $298 \mathrm{~K}$. The used specimen is $\mathrm{Mg}-9$ mass\% $\mathrm{Al}$ alloy anodized for $10 \mathrm{~min}$ at various constant potentials.

mol $\mathrm{dm}^{-3} \mathrm{NaOH}$ solution. The anti-corrosion properties of the anodized specimens at each constant potential were better than those of non-anodized specimens. The specimen anodized at an applied potential of $3 \mathrm{~V}$ had the best anticorrosion properties because there was a large shift in potential in the noble direction with increasing corrosion current. Corrosion potential defined the potential at which the current density reached $0.1 \mathrm{~mA} \mathrm{~cm}^{-2}$ in 9 mass $\% \mathrm{Al}$ from anodic polarization curve of Figure 4. and compared corrosion potentials between the various alloys as an indicator of corrosion resistance. Corrosion potentials in pure $\mathrm{Mg} . \mathrm{Mg}-3$ mass $\% \mathrm{Al}$ calculated in same manner with 9 mass $\% \mathrm{Al}$.

Table 1 summarizes the potential. $E_{\text {curr }}$ corresponding to a current density of $0.1 \mathrm{~mA} \cdot \mathrm{cm}^{-2}$ for pure $\mathrm{Mg}$. $\mathrm{Mg}-3$ mass $\%$ $\mathrm{Al}$. and $\mathrm{Mg}-9$ mass $\% \mathrm{Al}$ alloys. The anodized films degraded at current densities above $0.2 \mathrm{~mA} \mathrm{~cm}{ }^{-2}$. To evaluate the anodic films before they degraded, we compared the potentials at a current density of $0.1 \mathrm{~mA} \mathrm{~cm}$. The anti-corrosion property of $\mathrm{Mg}-9$ mass\% $\mathrm{Al}$ was better than that of $\mathrm{Mg}-3$ mass\% $\mathrm{Al}$ alloy. Al has a beneficial effect on the passivity: which leads to the high corrosion resistance of Mg-Al alloys. ${ }^{1819}$ The best anti-corrosion effect was obtained with anodizing at $3 \mathrm{~V}$, and the next best at $80 \mathrm{~V}$. Therefore. anodizing potentials of 3 and $80 \mathrm{~V}$ were used in the subsequent experiments.

The current densities of alloy specimens anodized for 10

Table 1. Comparison of $E_{\text {carr }}$ corresponding to a cument density of $0.1 \mathrm{~mA} \cdot \mathrm{cm}^{-2}$

\begin{tabular}{llllll}
\hline $\begin{array}{c}\text { Anodized } \\
\text { potential }\end{array}$ & $\begin{array}{c}\text { Non- } \\
\text { anodizing }\end{array}$ & $3 \mathrm{~V}$ & $10 \mathrm{~V}$ & $40 \mathrm{~V}$ & $80 \mathrm{~V}$ \\
\hline Pure Mg & $-1.670 \mathrm{~V}$ & $-1.726 \mathrm{~V}$ & $-1.741 \mathrm{~V}$ & $-1.747 \mathrm{~V}$ & $-1.720 \mathrm{~V}$ \\
$\mathrm{Mg}-3 \mathrm{mass} \% \mathrm{Al}$ & $-1.518 \mathrm{~V}$ & $-1.250 \mathrm{~V}$ & $-1.500 \mathrm{~V}$ & $-1.467 \mathrm{~V}$ & $-1.395 \mathrm{~V}$ \\
$\mathrm{Mg}-9 \mathrm{mass} \% \mathrm{Al}$ & $-1.490 \mathrm{~V}$ & $-1.160 \mathrm{~V}$ & $-1.455 \mathrm{~V}$ & $-1.410 \mathrm{~V}$ & $-1.369 \mathrm{~V}$ \\
\hline
\end{tabular}




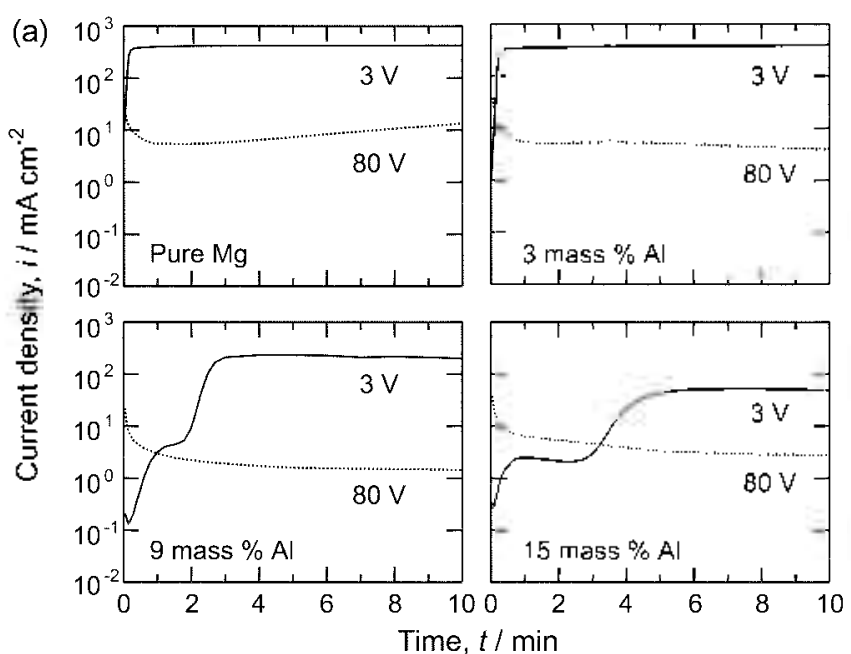

(b)

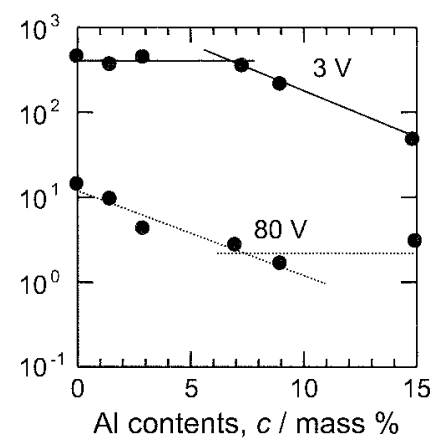

Figure 5. Comparison of the cument density after anodizing for 10 min with $\mathrm{Al}$ contents in $1.0 \mathrm{mmol} \cdot \mathrm{dm}^{-3} \mathrm{NaOH}$ solution at $298 \mathrm{~K}$

min in $1.0 \mathrm{~mol} \mathrm{dm} \mathrm{dm}^{-3} \mathrm{NaOH}$ solution at $298 \mathrm{~K}$ are compared in Figure 5. As shown in Figure 5(a). stagnation of the current density for 9 mass $\% \mathrm{Al}$ in the case of $3 \mathrm{~V}$ occurred at a current density of about $2 \mathrm{~mA} \mathrm{~cm}-$. The stagnation time increased with the aluminum content. resulting in a decrease in the current density after $10 \mathrm{~min}$ (Figure 5(b)). The plateau phenomenon in 15 mass $\%$ Al will treat in Figure 8. Moreover at $80 \mathrm{~V}$, the current density after $10 \mathrm{~min}$ decreased with 9 mass $\% \mathrm{Al}$. but was slightly higher with 15 mass $\% \mathrm{Al}$.

Figure 6 shows anodic polarization curves in $0.017 \mathrm{~mol} \mathrm{dm}^{-3}$ $\mathrm{NaCl}$ and $0.1 \mathrm{~mol} \cdot \mathrm{dm}^{-3} \mathrm{Na}_{2} \mathrm{SO}_{4}$ at $298 \mathrm{~K}$. Specimens with different $\mathrm{Al}$ contents were anodized at an applied potential of $3 \mathrm{~V}$ in $1 \mathrm{moldm}^{-3} \mathrm{NaOH}$ for $10 \mathrm{~min}$ at $298 \mathrm{~K}$. The potential shifted in the noble direction with increasing aluminum content. while the polarization curve of $\mathrm{Mg}-15$ mass $\% \mathrm{Al}$ had a distinct shape. The potential of 15 mass $\%$ Al for current densities of $0.15-2.3 \mathrm{~mA} \mathrm{~cm}^{-2}$ was lower than that of 9 mass $\% \mathrm{Al}$. The photographs of the anodized surface show that dissolution of the $\alpha$ phase occurred at an applied potential of $3 \mathrm{~V}$ regardless of the $\mathrm{Al}$ content. The $\alpha$ phase in 15 mass $\% \mathrm{Al}$ took the form of a large hole. Moreover. the twostep current plateau increase was insufficient with anodizing for $10 \mathrm{~min}$. Consequently. Mg-15 mass $\% \mathrm{Al}$ was anodized for $30 \mathrm{~min}$ at $3 \mathrm{~V}$ in $1 \mathrm{~mol} \cdot \mathrm{dm}^{-3} \mathrm{NaOH}$ at $298 \mathrm{~K}$

Figure 7 shows the changes in current (a) and surface morphology (b) with time on anodizing at $3 \mathrm{~V}$ of 15 mass $\%$ Al in $1 \mathrm{~mol} \cdot \mathrm{dm}^{-3} \mathrm{NaOH}$ at $298 \mathrm{~K}$. The current density was

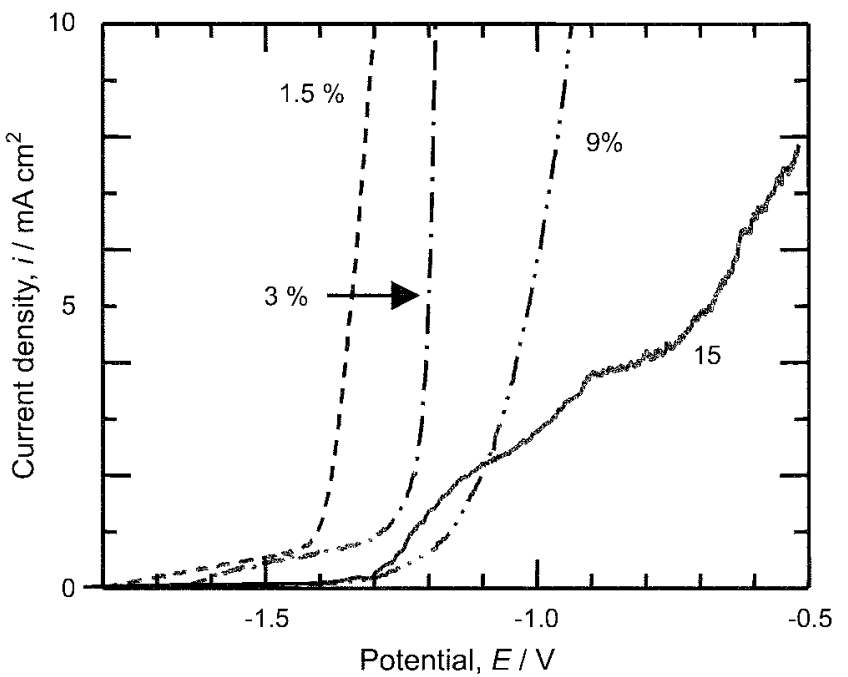

Figure 6. Anodic polarization curves in $0.017 \mathrm{~mol} \cdot \mathrm{dm}^{-\hat{3}} \mathrm{NaCl}$ and $0.1 \mathrm{~mol} \cdot \mathrm{dm}^{-3} \mathrm{Na}_{2} \mathrm{SO}_{4}$ solution at $298 \mathrm{~K}$. The specimens were anodized at an applied potential of $3 \mathrm{~V}$ with $\mathrm{Al}$ contents $1 \mathrm{~mol}^{-\mathrm{dm}^{-3}}$ $\mathrm{NaOH}$ solution for $10 \mathrm{~min}$ at $298 \mathrm{~K}$

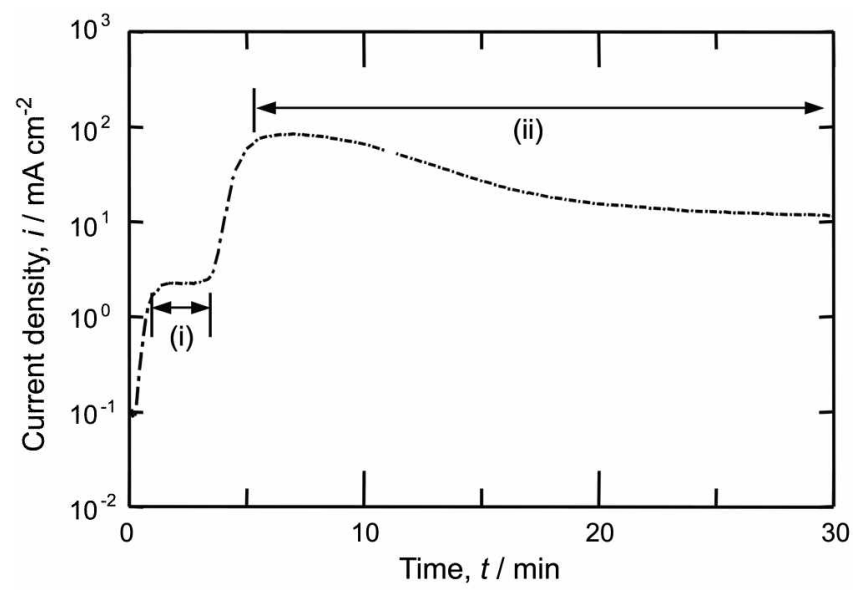

(a) ; (i) Formation of film on $\beta$ phase, (ii) Formation of film on $\alpha$ phase

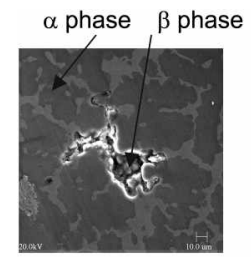

(i)

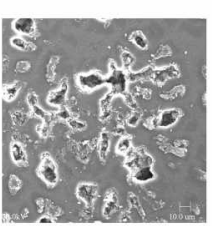

(ii)

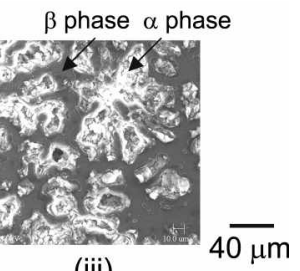

(iii) (b) ; (i) After anodizing $2.5 \mathrm{~min}$, (ii) After anodizing $10 \mathrm{~min}$, (iii) After anodizing $30 \mathrm{~min}$

Figure 7. Effect of anodizing time affecting to i-t curves and surface morphologies in anodizing at an applied potential of $3 \mathrm{~V}$ for $15 \mathrm{mass} \% \mathrm{Al}$ in $1.0 \mathrm{~mol} \cdot \mathrm{dm}^{-3} \mathrm{NaOH}$ solution at $298 \mathrm{~K}$.

maximal at an anodizing time of $7 \mathrm{~min}$. Thereafter. the current density gradually diminished and was about 10 $\mathrm{mA} \mathrm{cm}^{-2}$ after $30 \mathrm{~min}$. It seemed that an anodizing film formed via a dissolution reaction on the $\beta$ phase at 2 $\mathrm{mA} \mathrm{cm}^{-2}$ for 1-4 min. as no stagnation of current density with low aluminum content ( 3 mass $\% \mathrm{Al}$. Figure 5(a)) was seen at ca. $2 \mathrm{~mA} \mathrm{~cm}^{-2}$, as is seen in pure magnesium. This 


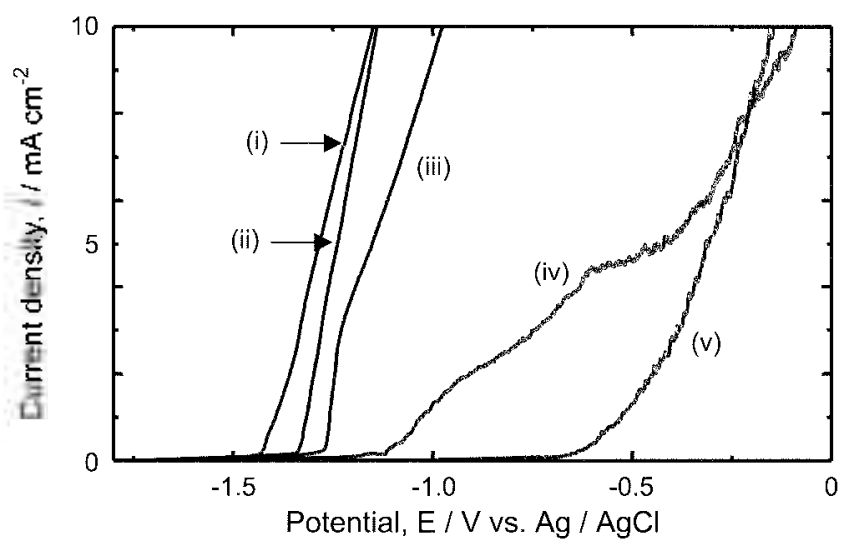

(1) Non-anodizing, (11) $3 \mathrm{~mm}$, (111) $5 \mathrm{~mm}$, (1v) $10 \mathrm{~mm}$, (v) $30 \mathrm{~mm}$

Figure 8. Anti-corosion property with anodizing time for 15 mass \% Al in $0.017 \mathrm{~mol} \cdot \mathrm{dm}^{-3} \mathrm{NaCl}$ and $0.1 \mathrm{~mol} \cdot \mathrm{dm}^{-3} \mathrm{Na}_{2} \mathrm{SO}_{4}$ solution at $298 \mathrm{~K}$. Anodizing was carried out at conditions for 10 min at $3 \mathrm{~V}$ in $1 \mathrm{mnol} \mathrm{dm}^{-3} \mathrm{NaOH}$ solution at $298 \mathrm{~K}$.

was ascertained in SEM studies of the surface morphology (Figure 7(b)(i)). It seemed that a film formed on the $\alpha$ phase at a current density of approximately $10^{2} \mathrm{~mA} \mathrm{~cm}^{-2}$, because all the specimens were similar as seen by SEM (Figure 7(b) (ii. iii)). As compact films did not form on specimens anodized for $10 \mathrm{~min}$. it appears that the current density increases in the anodic film formed on the $\alpha$ phase. beginning at around $-1.2 \mathrm{~V}$. because the anodic film formed in the $\alpha$ phase is a non-compacted film. Subsequently. the current density abruptly increased at a potential of $-0.4 \mathrm{~V}$ (Figure 8). When anodized for $30 \mathrm{~min}$, the anodic film on the $\alpha$ phase was more compact than that at $10 \mathrm{~min}$. Therefore. with anodization for $30 \mathrm{~min}$. the anodic polarization curve was the same shape as that for specimens anodized at other potentials. In addition. when anodized for more than $30 \mathrm{~min}$. the polarization curves were similar to that for $30 \mathrm{~min}$.

However we were not convinced that the $\alpha$ and $\beta$ phases are present in Figure 7 . Therefore. EDX analy sis was used to verify the presence of the $\alpha$ and $\beta$ phases without (a) and with (b) anodization for $10 \mathrm{~min}$ at $3 \mathrm{~V}$ for 15 mass $\% \mathrm{Al}$ in 1 $\mathrm{mol} \cdot \mathrm{dm}^{-3} \mathrm{NaOH}$ as shown in Figure 9. Without anodizing (a). the EDX analysis confirmed the phases in regions (1)

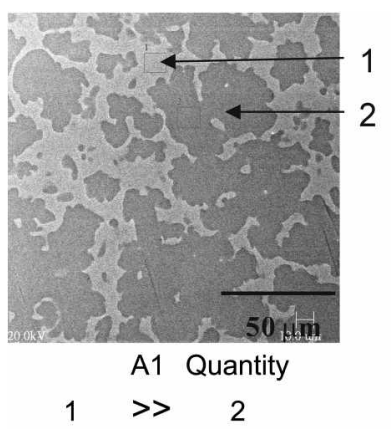

(a) No anodizing

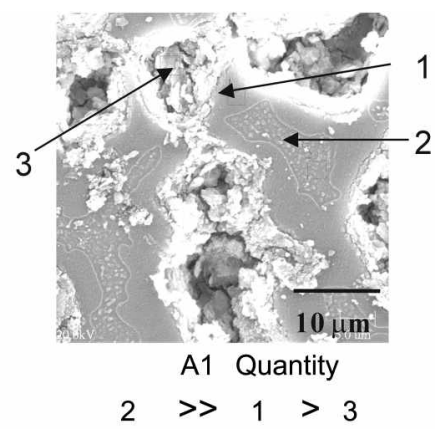

(b) Anodizing
Figure 9. Surface morphologies in without (a) and with (b) anodized for $10 \mathrm{~min}$ at $3 \mathrm{~V}$ for 15 mass $\% \mathrm{Al}$ in $1 \mathrm{~mol} \cdot \mathrm{dm}^{-3} \mathrm{NaOH}$ solution at $298 \mathrm{~K}$.

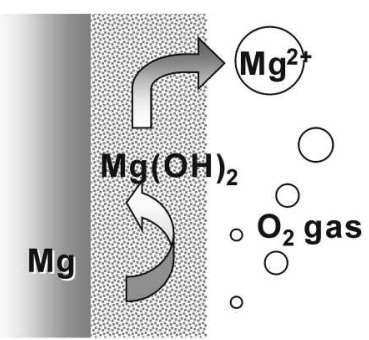

(a) $3 \mathrm{~V}$

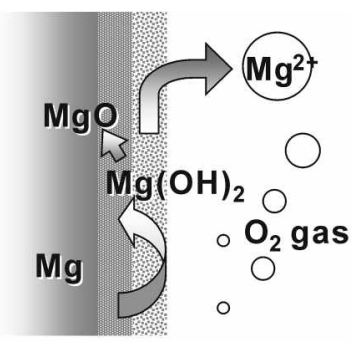

(b) $80 \mathrm{~V}$
Figure 10. Schematic diagram on formation mechanism of anodic tilin.

and (2). The Al content in region (1) far exceeds that in region (2). This indicated that region (l) is the $\beta$ phase and region (2) is the $\alpha$ phase. With anodizing (b), the Al content in regions (1) to (3) was in the order: region (2)" region (1) $>$ region (3). Over time the active dissolution reaction during anodizing occurred preferentially at the $\beta$ phase until about $4 \mathrm{~min}$. Then, the current density gradually increased until $7 \mathrm{~min}$. The dissolution reaction progressed on $\alpha$ phase. which had a lower $\mathrm{Al}$ content.

These results suggest that the mechanism of anodic oxide film fomation on a specimen of $\mathrm{Mg}-\mathrm{Al}$ alloy anodized in $1.0 \mathrm{~mol} \cdot \mathrm{dm}^{-3} \mathrm{NaOH}$ solution is as follows. Metal substrate/ film and film/electrolyte interfaces occur during generation of the film (Figure 10). The interface at a low potential, like $3 \mathrm{~V}$. is a metal substrate/film interface. The dissolution reaction of magnesium $\left(\mathrm{Mg} \rightarrow \mathrm{Mg}^{2+}+2 \mathrm{e}^{-}\right)$occurs. The $\mathrm{Mg}$ quickly combines with $\mathrm{OH}^{-}$in the $\mathrm{NaOH}$ solution $\left(\mathrm{Mg}^{2-}+\right.$ $\left.2 \mathrm{OH}^{-} \rightarrow \mathrm{Mg}(\mathrm{OH})_{2}\right)$.

A MgO film fomed at a high potential of $80 \mathrm{~V}$. although extremely small $\mathrm{Mg}(\mathrm{OH})_{2}$ peaks were also observed in the XRD analyses of specimens anodized at various constant potentials. The temperature at the specimen surface increased at high potentials. such as $80 \mathrm{~V}^{20}$ The reaction in formula (1) seen with increasing temperature is thought to be the partial reaction of $\mathrm{Mg}(\mathrm{OH})_{2}$.

$$
\mathrm{Mg}(\mathrm{OH})_{2} \rightarrow \mathrm{MgO}+\mathrm{H}_{2} \mathrm{O}
$$

Anodizing is accompanied by intensive sparking and oxygen evolution. ${ }^{x} 21.22$ Therefore, formula (2) occurred at the film/electrolyte interface.

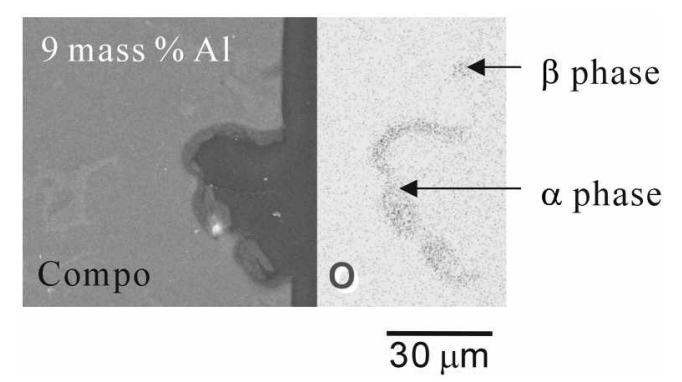

Figure 11. SEM photography and EDX analysis of cross section of $\mathrm{Mg}-9$ mass\%Al alloy anodized for $10 \mathrm{~min}$ at $3 \mathrm{~V}$ in $1 \mathrm{~mol} \cdot \mathrm{dm}^{-3}$ $\mathrm{NaOH}$ solution at $298 \mathrm{~K}$. 


$$
\mathrm{Mg}(\mathrm{OH})_{2} \rightarrow \mathrm{Mg}^{2-}+1 / 2 \mathrm{O}_{-} \uparrow+\mathrm{H}_{2} \mathrm{O}+2 \mathrm{e}^{-}
$$

Figure 11 shows an EDX map of a cross-section of a specimen of $\mathrm{Mg}-9$ mass $\% \mathrm{Al}$ anodized for $10 \mathrm{~min}$ at $3 \mathrm{~V}$ in $1.0 \mathrm{~mol} \cdot \mathrm{dm}^{-3} \mathrm{NaOH}$ at $298 \mathrm{~K}$. The film that formed on the $\alpha$ phase was about $10 \mu \mathrm{m}$ thick. i.e. the oxygen region. This suggests that $\mathrm{Mg}(\mathrm{OH})$; was generated in this region.

\section{Conclusion}

The anti-corrosion properties of anodized specimens were excellent. as compared with those of non-anodized specimens. When $\mathrm{Mg}$ - $\mathrm{Al}$ alloys were anodized, a $\mathrm{Mg}(\mathrm{OH})$ : film was primarily seen at an applied potential of $3 \mathrm{~V}$. while a $\mathrm{MgO}$ film appeared at an applied potential of $80 \mathrm{~V}$. The intensity ratio of the $\beta$ phase increased with aluminum content in the $\mathrm{Mg}$-Al alloys. Over time. the active dissolution reaction during anodizing occurred preferentially on the $\beta$ phase until about $4 \mathrm{~min}$. Then, the current density increased gradually with time until $7 \mathrm{~min}$. After anodizing for $10 \mathrm{~min}$. the current density increased when the aluminum content was 15 mass $\%$. since the anodic film that forms on the $\alpha$ phase is a non-compact film. The anodic film on the $\alpha$ phase at 30 min was compact compared with that at $10 \mathrm{~min}$.

Acknowledgements. The authors would like to acknowledge support for this research from the Japan Society for the Promotion of Science.

\section{References}

1. Suzuki, K. Alutopia 2000. 5,40.
2. The European Parliament and Council: Draft proposal for a direct on the restriction of the use of certain hazardous substances in electrical and electronic equipment. Tune 2000.

3. Kunieda. N. I07th Meeting of the Surface Finishing Society of Japan1. 2003: p 296.

4. Kim. S. J:- Okido. M. Sealing improved film properties atter anodizing of Mg-Al alloys. Bull. Korea Chent. Soc. submitted.

5. Kim. S. J.: Okido, M: Ichino, R: Mizutani, Y; Tanikawa. S:; Hasegawa. H. Haterials Transactions 2003. 4t. 1036.

6. Kimn. S. T.: Zhou. T.: Ichino. R.: Okido. M.: Tanikawa. S. Metals and Materials International 2003. 9. 207.

7. Kim. S. J; Hara, R.: Ichino. R.: Okido. M.: Wada. N. Materials Transactions $2003,4.782$

8. Emley. E. F. Principle of Maghesium Techologv: Pergamon Press: London. 1966: 122

9. Huber. K. J. Electrochem. Soc. 1953. 100. 376.

10. Evangelides. H. A. Metal Finishing 1951. 7.56.

11. Ono. S.: Asami. K.: Osaka, T.: Masuko, N. J. Electrochem. Soc. 1996. $1+3, \mathrm{~L} 62$

12. Khaselev. O.: Yahalon. J. J. Electrochem. Soc 1998, 145. 190.

13. Khaseley. O.: Yahalon. J. Comosion Sci. 1998. 40.1149.

14. Oh. H. T.: Chi. C. S. Bull. Konan Chem. Soc. 2000. 21. 193

15. Ono. S.: Kijima. H.: Masuko. N. J. Japan Whstitute of Light Metals 2002. 52,115

16. Ono. S.: Kijima. H.: Masuko. N. J. of the Surface Finishing Society of Japan 2000, 51,1168 .

17. Mizutani. Y.: Kim. S. T.: Ichino. R.: Okido. M. J. Surf. \& Coating Tech. 2003. 169-170. 143

18. Lunder. O.: Lein. T. E.: Aune. T. K.: Nisancioglu. K. Conosion 1989. 45,741

19. Makar. G. L.: Kruger J. J. Electrochem. Soc. 1990, 137, 414.

20. Zhang. Y.: Yan, C.: Wang, F; Lou. H. Cao, C. J. Surf \& Coating Tech. 2002. 161. 36 .

21. Khaselev. O.: Weiss. D.: Yahalon. J. J Electrochem. Soc. 1999. I+6. 1757

22. Khaselev. O.: Weiss, D.: Yahalon. J. Corosion $S_{c i} \mathbf{2 0 0 1},+3$. 1295. 